A N N A L E S

UNIVER S T A T IS MARIAE CURIE-SKŁODOW S A LUBLIN - POLONIA

VOL. XXIX, 2

SECTIO J

2016

National Academy of Educational Sciences of Ukraine, Kiev, Ukraine

\title{
OLGA SUKHOMLYNSKA
}

2991946@gmail.com

\section{Ukrainian and Polish Pedagogical Influences in the Historical Dimension: The Case of Vasyl Sukhomlynskyi}

Ukraińsko-polskie wzajemne wpływy pedagogiczne w wymiarze historycznym:

Przypadek Wasyla Suchomłyńskiego

\begin{abstract}
The article is devoted to the importance of the Ukrainian-Polish pedagogical relations for the development of the modern education quality and building a common European home. The historical expertise has its importance for a better understanding the contemporary course of action; the previous achievements in the contemporary intercultural pedagogical space are discussed. It is also elaborated, as an example, the figure of Vasyl Sukhomlynskyi, the Ukrainian pedagogue, and his creative heritage, relations with the Polish colleagues between the 1950s and the1960s, as well as the influence of Janusz Korczak, the famous Polish educator, on his viewpoint. The development of the Ukrainian-Polish relations and the further influences over the next decades were presented too. There is conducted an analysis on the translation of Sukhomlynskyi's works in Poland and the popularization of his ideas by the well-known Polish teachers and researchers, including Aleksander Lewin, Wincenty Okoń, Marian Byblyuk and others. It is underlined a micro-historical approach prospect that allows one to consider the overall process in the light of the individual's experiences, with educational heritage as an intercultural space component.
\end{abstract}

Key words: education; mutual understanding; teacher; pedagogy; development; influences; publication; book; Poland; Ukraine 


\section{INTRODUCTION}

The theme of interstate and intercultural influences on aspects of social activity in the process of its development is extremely widespread. An important role of it belongs to the investigations within the area of pedagogical relations, which not only show the state of affairs in the field of education and upbringing in different societies, but also have an influence on strategy and tactic development in it, especially in some turning points, as it is nowadays.

Ukraine and Poland are close neighbors, associated with a universal history. Both countries look for the points of mutual understanding, positive examples and approaches, which let them make a closer co-operation in general pedagogical area.

During the last years in this area it has been done more than in prior decades, especially in the university education: organization of activity, methods of teaching and subject matters.

The co-operation between universities of the two countries is developing and shows the essential influence, which is made owing to the factors such as: choosing the European way of the state development, successful economic growth and social reforms including education, the idea of the university education as an important part of public policy.

But it is also interesting to study these processes from the point of history of the two countries, which has provided a basis of modern interrelations. Among the Ukrainian works of such a degree we are going to point out those, which are related to the development of Polish education on the territory of Volyn'-Zhytomyr (Right-bank Ukraine). The period of time the Ukrainian researchers are interested in is between the 1920s and the early 1930s. It is a time of a positive activity, or national equating; the policy led by the USSR gave the national minorities the possibility to study in their native languages. Among the authors we should mention here N. Seiko who wrote Pedagogical and Ethnosociological Foundations of the Development of Polish Education in Volyn'-Zhytomyr Region in 1905-1938 (1999) and S. Koliadenko with her Kremenets Lyceum in the System of Education in Volyn' in the $19^{\text {th }}$ Century-'30s of the $20^{\text {th }}$ Century.

These researches and some other sources give us the possibility to study a large historical background of pedagogical interrelations.

\section{IMPACT OF KORCZAK'S WORKS ON SUKHOMLYNSKYI'S PEDAGOGICAL CONCEPT}

The reference to the micro-history, as a process of humanization and personification of the whole historical background, is the most fruitful research direction nowadays. With the help of it we can work deeper the inner sense of the com- 
mon processes through the single one. We use this method to light up the PolishUkrainian interrelations through the life and fate of a famous Ukrainian teacher, columnist and pedagogue Vasyl Sukhomlynskyi, who worked in the period of 1950s-1960s. He is famous abroad owing to his works, especially to his book My Heart I Give to Children. In this book, the name of Janusz Korczak was mentioned not just to show the great Polish teacher, but also to give the example which is worth following. Sukhomlynskyi named his Polish colleague an "extremely wonderful moral person", whose life and works offered such a great inspiration. Sukhomlynskyi said: "I understood that to be the genuine teacher for children means to devote them my life". As we can say, his main book was titled due to the great impression of Korczak's works. Sukhomlynskyi used a lot of quotations from Korczak's works, but the analysis of their frequency has not yet been done. Polish scientists placed high emphasis on the Soviet education in general, and on Sukhomlynskyi himself, as a headmaster and the author of scientific works, during the period of 1950s-1960s. Since 1954, the articles of the famous Ukrainian teacher, which uncover different aspects of upbringing, have been published in Polish periodicals. To my mind, the interest of Polish teachers in Sukhomlynskyi was due to the reason that the postwar Poland had to rebuild the system of education upon the Soviet model. The fact that Sukhomlynskyi has attracted the attention can be explained by his ability to write in vivid language and his experience. Twelve articles by him have been published in Polish pedagogical periodicals during Sukhomlynskyi's life.

\section{OCCURRENCE OF SUKHOMLYNSKYI'S IDEAS IN POLISH PEDAGOGICAL LITERATURE}

Polish researchers who studied the experience of education development in the USSR or had an interest in the Soviet pedagogical sphere, have paid attention to the new experimental way in pedagogical sphere by Sukhomlynskyi and the activity of the Pavlysh High School. For example, a Polish scientist Tadeusz Wiloch (1927-1995) have been visiting Pavlysh at the end of the 1950s-1960s and lived with Sukhomlynskyi's family. As a result of this, there was written a book, published in 1962 - The Soviet Educational and Upbringing System, in which the labor education in Pavlysh was described. He wrote and published reviews of Sukhomlynskyi's works, such as Human Is Unique (1962) and Education of the Individual in the Soviet School (1965), etc.

A special interest in the heritage of the Ukrainian teacher was noticed after his death (after 1970). Publication of his articles in Polish periodicals, increasing popularity in the USSR, publication of the book My Heart I Give to Children (1968 in GDR, 1969 in the UkSSR) and debates about the person of Sukhomlynskyi caused such an interest. 
We are going to mention Aleksander Lewin (1915-2012), a famous teacher, professor, the enthusiast of Korczak. He also focused on the problems of socialvulnerable children, and was a headmaster of the establishments of such a kind. Lewin investigated the development of humanistic ideas through the works of J. Korczak, A Makarenko and C. Freinet. He also visited Anna Sukhomlynska, the widow of Sukhomlynskyi, at the beginning of the 1980s.

The most outstanding popularizer of Sukhomlynskyi's heritage from the end of 1970s was a professor of the Nicolaus Copernicus University in Torun, Marian Bybluk. He published many articles in Polish periodicals, and books: Pedagogical Concept and Educational System by Vasyl Sukhomlynskyi (1982) and The Sukhomlynskyi's School of Joy (1990). The works written by Bybluk reflect the deep understanding of educational processes in the Soviet Union, characterize the great contribution of Sukhomlynskyi to the education and upbringing, and the specific character of his approaches. In his latest work The Revival and Development of Education in the Independent Ukraine (2011), he reveals the perception and evaluation of the Sukhomlynskyi's heritage by contemporary Ukrainian pedagoguesscientists, which compare his ideas with the concepts of Anton Makarenko and Grigoriy Vashchenko.

We also point out the book by the famous Polish methodologist and Professor Wincenty Okoń (1914-2011) - Ten Alternative Schools (1997), where among the schools known throughout the world, such as Célestin Freinet's, Alexander Neil's and others, the school in Pavlysh was mentioned as "Pavlysh School of Vasily Sukhomlynskyi" too. Another reason was the appearance of Sukhomlynskyi's works translated into Polish at the end of the 1970s-beginning of the 1980s in Poland. The Moscow publishing house "Progress" started to work at editions of two books by Sukhomlynskyi in Polish: My Heart I Give To Children (1979) and The Birth of the Citizen (1982). But the translations were not accepted by most of the Polish scientists. They began to translate the books on their own, and write the articles, because it seems that they did not like the pressure aside. The first one was My Heart I Give To Children, translated by Bybluk, with the introduction by Lewin (1978), and then it was another book - A Few Words About Upbringing, edited in Warsaw in 1982.

According to our data, the last book by Sukhomlynskyi, translated in Poland, was One Hundred Advice for Teacher (1987), but now his books are not published because of different reasons, and one of them - the end of the ideology, which Sukhomlynskyi was regarded as a part of.

Nevertheless, he is still the part of Polish pedagogical area, which is confirmed by the frequency of Internet requests in Poland: Google - 604 results (compare with Russia - 390,000, Ukraine - 191,000 requests). 
Since the Ukrainian-Polish pedagogical and scientific interrelations have been growing during the last few years, researches of Sukhomlynskyi's heritage will be continued. For example, it may be the epistolary heritage, letters of Sukhomlynskyi to Wiloch, the analysis of translated texts in Moscow and Poland, etc.

\section{REFERENCES}

Bybluk, M., Koncepcja pedagogiczna i system wychowawczy Wasyla Suchomlińskego, UAM, Toruń 1982.

Bybluk, M., Radosna szkoła Suchomlińskego, UAM, Warszawa-Toruń 1990.

Bybluk, M., Odrodzenie i rozwój oświaty na niepodległej Ukrainie 1991-2010. Studia i szkice historyczno-pedagogiczne, Wydawnictwo Kujawsko-Pomorskiej Szkoły Wyższej, Bydgoszcz 2011.

Koliadenko, S.M., Kremenetskyi litsei u systemi osvity Volyni (XIX-30-ti rr. XX st.), Kyiv 2007.

Kozhenovskyi, M., Za Zolotymy voritmy. Suspilno-kulturna diialnist poliakiv u Kyievi v 1905-1920 rokakh, Dukh i litera, Kyiv 2015.

Seiko, N.A., Pedahohichni ta etnosotsiolohichni zasady rozvytku polskoho shkilnytstva na VolyniZhytomyrshchyni u 1905-1939 rr., Kyiv 1999.

Suchomliński, W.A., Przewodnik i nauczyciel, [in:] O pracy organizacji pionierskiej, R. Muranyi (transl.), PZWS, Warszawa 1954.

Suchomliński, W.A., Pierwiastek estetyczny w wszechstronnym rozwoju człowieka, "Kwartalnik pedagogiczny", 1960, no. 2.

Suchomliński, W.A., Elementarz kultury moralnej, "Wychowanie", 1964, no. 8.

Suchomliński, W.A., Me serce - dzieciom, Progress, Moskwa 1979.

Suchomliński, W.A., Narodziny obywatela, Progress, Moskwa 1982.

Suchomliński, W.A., Oddaj serce dzieciom (transl. M. Bybluk, introd. A. Lewin), WSiP, Warszawa 1978.

Suchomliński, W.A., Słów kilka o wychowaniu (introd. A. Lewin), WSiP, Warszawa 1982.

Suchomliński, W.A., Sto rad dla nauczyciela, WSiP, Warszawa 1987.

Teri, M., Imperiia natsionalnoho vyrivniuvannia. Natsii ta natsionalizm u Radianskomu Soiuzi (1923-1939 roky), Krytyka, Kyiv 2013.

Ukrainska istoryko-pedahohichna nauka u dzerkali tematyky dysertatsiinykh doslidzhen (19952014). Khronolohichno-tematychnyi pokazhchyk, edition FOP Zhovtyi, Uman 2014.

Wiloch, T., Radziecki system oświatowo-wychowawczy, PWN, Warszawa 1962.

\section{STRESZCZENIE}

Artykuł poświęcony jest znaczeniu pedagogicznych relacji ukraińsko-polskich dla podniesienia jakości nowoczesnej edukacji i budowy wspólnego europejskiego domu. Wykazuje również znaczenie wykorzystania doświadczenia historycznego dla pełniejszego rozumienia odbywających się obecnie procesów w celu interpretacji osiągnięć przeszłości we współczesnej międzykulturowej przestrzeni pedagogicznej. Wybrano tu jako przykład postać i dorobek twórczy ukraińskiego pedagoga Wasyla Suchomłyńskiego, jego relacje z polskimi kolegami w latach 50. i 60. XX w. oraz wpływ na jego poglądy pedagogiczne słynnego polskiego pedagoga Janusza Korczaka. Scharakteryzowano również dalszy rozwój stosunków ukraińsko-polskich w ciągu najbliższych dziesięcioleci. W artykule przeanalizowano tłumaczenia książek Suchomłyńskiego w Polsce. Została też uka- 
zana popularyzacja jego pomysłów przez znanych polskich pedagogów-badaczy, w tym Aleksandra Lewina, Wincentego Okonia, Mariana Bybluka i innych. Podkreślono perspektywę podejścia mikrohistorycznego, które pozwala spojrzeć na ogólne procesy historii przez pryzmat losów szczególnego człowieka i jego spuścizny pedagogicznej jako elementu przestrzeni międzykulturowej.

Słowa kluczowe: edukacja; wzajemne porozumienie; pedagog; pedagogika; rozwój; wpływy; publikacja; książka; Polska; Ukraina 